\title{
Heart transplant and mechanical circulatory support-the last frontier?
}

\section{Om Prakash Yadava ${ }^{1}$}

Published online: 20 July 2020

(C) Indian Association of Cardiovascular-Thoracic Surgeons 2020
Thus sayeth the Lord, "A new heart also will I give you, and a new spirit will I put within you: and I will take away the stony heart out of your flesh, and I will give you a heart of flesh".

Ezekiel, Chapter 36, Verse 26

(American King James Version)

Though the first heart transplant in the world was done in 1967, and a laudable Indian attempt soon thereafter in 1968, the true Indian story started in 1994. Even that delayed start lacked the vibrance and energy, and the transplant and mechanical circulatory support (MCS) services snailed for two decades, to gain traction only in the last 5-7 years, mainly through the efforts of our colleagues below the latitude of $15^{\circ}$. In fact, the southern states of the country too started with the same inertia and remained a laggard till 2013-2014, a chiasmatic point, from where their numbers started looking skyward. The gap widened unrelentlessly, leading to an inequitable distribution of heart transplant services in the country, being largely concentrated in the southern 4 states and Maharashtra - why these contrasting and disparate trajectories?

The platitudinal explanations often offered-religious beliefs, myth, stigma, cultural factors associated with transplantation, as also lack of infrastructure and logistics involved in transportation, etc.- fall flat when one realises that all these factors were operating equally in south India, when they too were once laggards, arm-in-arm with their north Indian colleagues. Then suddenly, the former changed gears and their numbers went up, just as we, in north India, kept sitting on our haunches, basking in the glory of being "First".

Om Prakash Yadava

op_yadava@yahoo.com

1 National Heart Institute, New Delhi, India
Tamilnadu currently is numero-uno in heart transplants in the country. Tamilnadu's leadership in organ donation is not accidental. It is courtesy a proactive bureaucracy, supported by a willing political dispensation and egged on by an enthusiastic and committed transplant medical fraternity, not discounting the supportive and enabling role played by philanthropic non-governmental organisations (NGOs). All these elements seem to be missing in the north Indian story. I hate to admit, the ethos of 'Service' and 'Philanthropy' take a different hue in different parts of the country... and that says it all.

The fault, therefore, has to be shared equally and collectively by the medical fraternity, government and the society at large. We have lost out on all 3 fronts to our colleagues from downunder. Cannot help but salute them. We also need a Mary Lasker to teach us the value and virtue of 'Advocacy', and the need for lobbying with the puissant, and at times contumacious, bureaucracy of north India. A concerted campaign need to be started with the public, goading and sensitizing them for increased organ donation. Simultaneously, we the professionals in the field need to introspect - Have we done enough?

No doubt the establishment of the National Organ and Tissue Transplantation Organisation (NOTTO) for regulation and facilitation of organ transplantation has given an impetus to creating awareness, leading to an increase in the number of transplants. Their plans of making all district hospitals as retrieval centres is indeed laudable, albeit platonic, as there are no discernible facilities, infrastructural and human resources, for harvesting the organs in any district hospital in India. Nevertheless, since its inception in 2014, it has improved the coordination between donation, retrieval and final transplantation of the hearts. Even in north India, the numbers have increased. For example, at the All India Institute of Medical Sciences (AIIMS) in Delhi, whereas 31 transplants were done between 1994 and 2014, 25 have been done between 2014 and 2017. However, this number pales when compared to statistics from the southern states. Moreover, even though there has been an exponential increase in number of heart transplant centres in the country over the last few years, 
majority of them have not yet crossed double figures, raising serious doubts regarding the intent of these programmes. To the emotive lay population, Heart Transplant and MCS services give an impression of 'having arrived'. They are perceived as surrogate to skill and technological superiority of a centre, or an individual, over their peers. Are these perceptions thus being exploited and anecdotal transplants being used by the surgeons for ego boosting and one-upmanship, and by the institutions, as marketing gimmickry?

In India, almost 50,000 to 2,00,000 patients require heart transplant every year, with nearly a 1000 in Delhi alone, while the number of heart transplants conducted across the country are a paltry couple of hundred. Demand thus far outstrips the supply of organs. Heart donation and transplantation still remains an esoteric idea with a lot of people in India. So, we may have to look at novel ways of increasing organ donation. If one looks at the international statistics, Spain has 34 donors per million, while India has barely 0.03 per million. They achieved these impressive numbers by a very novel way of propagating organ donation. After death, organs are offered 'By default', unless an individual makes an explicit will or request that his organs should not be taken. I think, this is not only fair, but morally and ethically correct too, as the patient has the option of not donating organs and yet those likely to miss out on this last opportunity at 'Deliverance', for reasons other than their willingness to donate organs, shall be served, besides substantially increasing the donor pool-a win-win situation for all stake holders.

Just as we talk of donor shortages, an issue which merits an equal attention is the wastage of donor organs, for want of recipients. There are no published statistics available as to the number of organs wasted in India, though a sense has been provided in the Guest Editorial in this very issue [1]. Certainly, at least in north India, it is a significant problem, which conveniently has not been spoken about. A lot of surgeons have communicated in hushed tones, that 3-4 times as many hearts go waste, as are utilised, in a typical north Indian transplant set up. Shorter ischemia time permissible and issues relating to size-match may also contribute to suboptimum utilisation of the donated organs. However, a fair number of them are also lost for issues like no incentive, reticence, convenience and lack of dedication of operating at odd hours, besides issues related to affordability, connectivity and accessibility. Nowhere in medicine are the 3 'As'-Availability, Accessibility and Affordability, more relevant than in Transplant \& MCS services. We will have to make sure that these facilities are not just confined to the major metropolitan cities, but they must percolate down to the tier II and III cities to be meaningful. Moreover, logistical systems would have to be strengthened so that organ sharing occurs at national level, and not just local or regional.

Going back to where we started - the 'Title', heart transplant is certainly not the final frontier, for that would have to be lifestyle interventions. Nowhere in the world, leave alone India, would the demands for hearts be met and governments be able to afford paying for the treatment of lifestyle disorders. The number of heart failure patients is ever burgeoning, and pari-passu, the need for transplant and MCS are going to increase in the future. Moreover, no matter whatever ingenuity and excellence we may achieve, we will never be able to match the nature-given heart with a MCS. Primordial and primary prevention through holistic lifestyle is indeed the 'Last Frontier' - a message driven hard and true by the rampaging Corona pandemic too.

Just as I share the 'joie de vivre' of the Guest Editor, and in his own words, "It is certainly a matter of great joy for us that the specialty has matured to a stage where a special issue of the journal is being brought out..." [1], I lament that it took us 25 years to come to party! Albeit late, we sure are coming of age. Through this featured issue, we have tried to contribute our two pence to the laudable and noble cause of saving lives, through heart transplantation and mechanical support. Have we succeeded, is your verdict—which we shall keenly await.

\section{Reference}

1. Balakrishnan K. Heart transplantation in India- are we there yet? Indian J Thorac Cardiovasc Surg. 2020. https://doi.org/10.1007/ s12055-020-00987-0.

Publisher's note Springer Nature remains neutral with regard to jurisdictional claims in published maps and institutional affiliations. 